\title{
Phytosociological Survey of Weeds in Coffee Plants Irrigated Under Different Systems
}

\author{
Simônica Maria De Oliveira ${ }^{1}$, Abner José De Carvalho ${ }^{1}$, Ignacio Aspiazú ${ }^{1}$, Polyanna Mara De Oliveira ${ }^{2}$, \\ João Victor Santos Guerra ${ }^{1}$, Fernando Henrique Batista Machado ${ }^{1}$, Joseilton Faria Silva ${ }^{1}$, \\ Andrey Antunes De Souza ${ }^{1}$, Fernando Gomes Silva ${ }^{1} \&$ Marlon Lopes Lacerda ${ }^{1}$ \\ ${ }^{1}$ Universidade Estadual de Montes Claros, Janaúba, Minas Gerais, Brazil \\ ${ }^{2}$ Empresa de Pesquisa Agropecuária de Minas Gerais, Nova Porteirinha, Minas Gerais, Brazil \\ Correspondence: Simônica Maria de Oliveira, Universidade Estadual de Montes Claros, Janaúba, Minas Gerais, \\ Brazil. E-mail: simonica.agronomia@gmail.com
}

Received: August 24, 2020

doi:10.5539/jas.v12n11p179

\author{
Accepted: September 22, 2020 \\ Online Published: October 15, 2020 \\ URL: https://doi.org/10.5539/jas.v12n11p179
}

\begin{abstract}
The objective was to identify the species and quantify the importance value index of weeds in the cultivation of arabica coffee in two irrigation systems, at different times of the year, in the northern region of Minas Gerais. A phytosociological survey was carried out in each season of the year (spring, summer, autumn and winter) in an area cultivated with the species Coffea arabica, subjected to two irrigation systems (sprinkling and dripping). The coffee crop was implanted at a spacing of $3.5 \mathrm{~m}$ between rows and 0.7 meters between plants. The collection of weeds was performed using the standard method of the square inventory, which was launched between the lines of the crop. The identification of the species was carried out, the number of individuals was quantified, the dry mass, frequency, density, abundance, importance value index and coverage, and the similarity index. 33 weed species were identified, being the species with the highest IVI Euphorbia hirta, Brachiaria plantaginea, Digitaria horizontalis, Cyperus rotundus and Amaranthus spp. It was observed a higher occurrence of weeds from the monocot group in the sprinkler irrigation system while in the drip there were predominance of dicot plants.
\end{abstract}

Keywords: Coffea arabica, drip, irrigation, sprinkling

\section{Introduction}

The cultivation of coffee in Brazil has a high socioeconomic importance, since the country occupies the first place in the ranking of world production. Among the cultivated species, arabica coffee (Coffea arabica L.) it is the most commercially exploited, representing $72 \%$ of national production. The acreage of arabica coffee in the country amounts to about 1.7 million hectares, which corresponds to $81 \%$ of the total coffee area in Brazil. The largest area cultivated with the species is concentrated in the State of Minas Gerais, which is about 1.22 million hectares, corresponding to $69.6 \%$ of the area occupied with arabica coffee nationwide (CONAB, 2019).

The estimate of coffee production in Brazil in the 2019 harvest was 50.92 million bags, which represents a reduction of $17.4 \%$ in relation to the previous harvest, which was a positive biennial cycle (CONAB, 2019). Despite the biennial effect, the history of coffee production in Brazil shows an increase, this increase being certainly related to the increase in areas of coffee crops in production, many of them in new cultivation regions and in irrigated areas.

Irrigated coffee culture has grown in Brazil in recent years and has often been responsible for enabling the expansion of culture to marginal regions for the cultivation of the species, as is the case in the North of Minas Gerais. However, within an irrigated production system, weed problems are accentuated due to water availability in the soil throughout the year.

It is known that the establishment of a weed community depends on local conditions, such as soil type, climate, cultural practices used, seed bank, management adopted, among other factors (Adegas et al., 2010). Thus, both the climatic variations of the region throughout the seasons, and the use of different irrigation systems can influence the occurrence of weed weeds, making it difficult to manage in coffee plantations. 
The weed interference is one of the main biotic factors influencing the production of cultivated plants, due to the allelopathic effects, competition for light, nutrients and water, in addition to being hosts of pests and diseases and hindering the performance of operations such as harvesting, fertilizers and applications of phytosanitary products (Pitelli, 1985). The basis for the definition of an efficient strategy in the control of weeds is the knowledge of the weed flora of the cultivation areas (Maciel et al., 2010), thus, the phytosociological method can be seen as an important tool that allows making several inferences about the weed flora in question so that it is possible to define what will be done, in the appropriate form and time (Gomes et al., 2010), since it provides specific data on the species occurring, such as frequency, density and abundance, in addition to its relationship with the total weed population.

Several phytosociological studies have already been carried out for different cultures, however we do not know the flora of weeds in irrigated coffee in semi-arid regions, mainly because they are marginal regions for coffee growing, characterizing a new productive system. Thus, the objective of the present work was to identify the species and quantify the importance value index of weeds in an arabica coffee area, under two irrigation systems, in different seasons of the year, in the North of Minas Gerais.

\section{Material and Methods}

The study was carried out in an experimental area located in the irrigated perimeter of Jaíba-MG, at the coordinates $15^{\circ} 06^{\prime} 48^{\prime \prime} \mathrm{S}$ latitude and $48^{\circ} 05^{\prime} 29^{\prime \prime} \mathrm{W}$ of longitude, at an altitude of $460 \mathrm{~m}$. The region's climate is "AW" (rainy tropical, savannah with dry winter) according to the Köppen classification, with an average annual rainfall of $750 \mathrm{~mm}$ and an average temperature of $26^{\circ} \mathrm{C}$. The soil was classified as Quartossenic Latosoil. The air temperatures and rainfall patterns during the period of the experiment are shown in Figure 1.

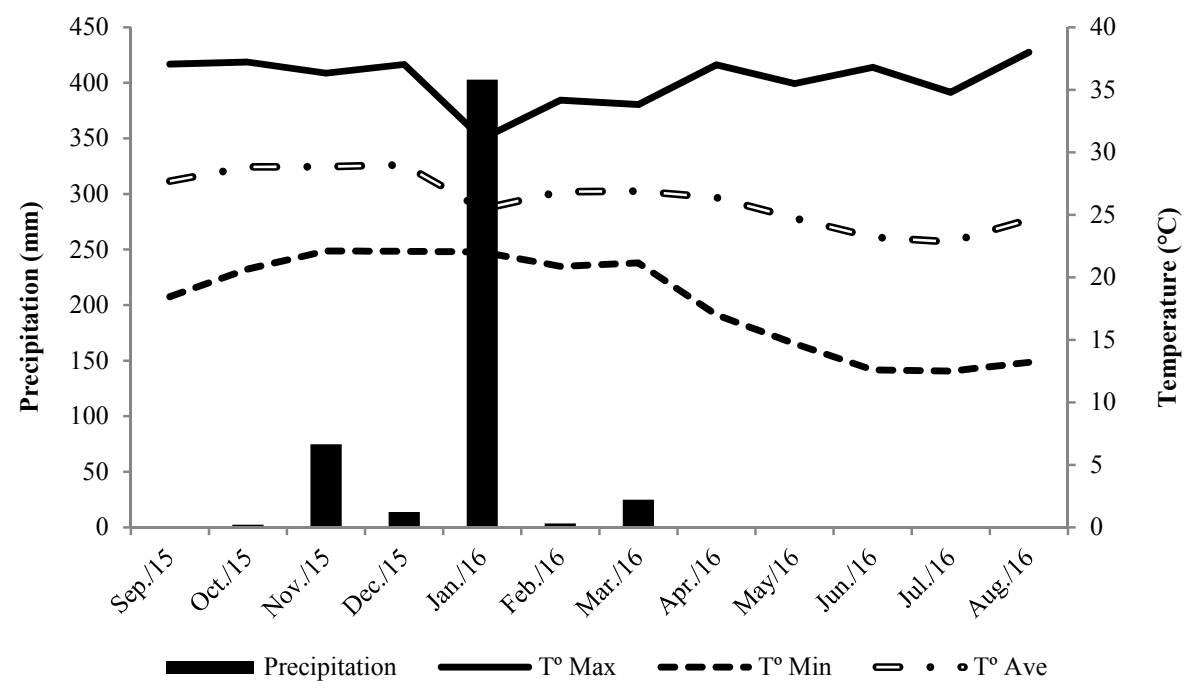

Figure 1. Precipitation (mm), Maximum, Average and Minimum Temperature $\left({ }^{\circ} \mathrm{C}\right)$ in Mocambinho-MG, during the conduction of the experiment

The work was carried out in two two-year-old arabica coffee plants, one irrigated by sprinkling and the other irrigated by drip. The crops were implanted at a spacing of $3.5 \times 0.7 \mathrm{~m}$, with one plant per hole corresponding to a density of 4,081 plants per hectare being installed following the recommendations for planting, training and cultural treatments as usually used in the region. Soil correction and NPK fertilization were carried out as a function of soil and leaf analysis of the area according to the recommendations of Guimarães et al. (1999).

For the drip irrigated area, the irrigation system consisted of main and secondary PVC lines and a $16 \mathrm{~mm}$ diameter low density polyethylene drip tube with emitters spaced $0.30 \mathrm{~m}$ apart. The nominal flow of the emitters is $5.5 \mathrm{~L} \mathrm{~h}^{-1}$ with service pressure of $100 \mathrm{kPa}$. A side line per row of plants was used, forming a continuous wet strip with an average width of $0.60 \mathrm{~m}$.

In the sprinkler irrigated area, conventional Rain Bird low flow sprinklers were used, with a gray nozzle and green ballerina. Applying for 24 meters of water column, $850 \mathrm{~L} \mathrm{~h}^{-1}$ with a range of 10.8 meters. The sprinklers were installed in the spacing of $12 \mathrm{~m} \times 14 \mathrm{~m}$, with a water application rate of $5.05 \mathrm{~mm} \mathrm{~h}^{-1}$. 
The management of water in irrigation was carried out considering the water balance in the soil, based on crop and meteorological data, collected in an automatic station, installed close to the areas.

Phytosociological surveys of weeds were carried out over a year, from September/2015 to August/2016. The infesting weeds in the areas were collected between the rows of the crop, and one collection was carried out in each season of the year (spring, summer, autumn and winter). All collections were made before weed control, which was carried out through mechanical mowing.

For the collection of weeds, the standard method of the square inventory was used $(0.5 \mathrm{~m} \times 0.5 \mathrm{~m})$, this being launched between the lines of culture 10 times, totaling $2.5 \mathrm{~m}^{2}$ of sampled area. The weeds were collected with complete structure, with root system and aerial part. In each sample, the plants were quantified and classified according to family, gender and species. Then, the samples of each species were packed in paper bags and taken to the oven with forced air circulation at $65{ }^{\circ} \mathrm{C}$ for 72 hours, for later weighing of the dry mass on a precision scale, the result being expressed in grams.

From the identification and counting of species, phytosociological variables were calculated: number of individuals per species, frequency (occurrence of species in each square), density (number of individuals of the same species in each square), abundance (concentration of species in different points in the area), dominance (determines the dominance of each species in relation to biomass production), relative frequency, relative density and relative abundance (relates one species to all others found in the areas), the importance value index, which represents the sum of the relative frequency, relative density and relative abundance, the coverage value index that expresses the species coverage in relation to their biomass production, and the similarity index, in percentage, which represents how similar the weed population between the compared areas.

In the calculation of phytosociological variables, the equations described below, proposed by Braun-Blanquet (1979) were used.

$\checkmark$ Frequency (F):

$$
\mathrm{F}=\frac{\text { Square containing species }}{\text { Total square used }}
$$

$\checkmark \quad$ Density (D):

Abundance (A):

$$
\mathrm{D}=\frac{\text { Total individuals by species }}{\text { Total area collected }}
$$

$$
\mathrm{A}=\frac{\text { Total individuals by species }}{\text { Total square containing the species }}
$$

$\checkmark \quad$ Relative frequency (FR):

$$
\mathrm{FR}=\frac{\text { Species frequency }}{\text { Total frequency of all species }} \times 100
$$

$\checkmark \quad$ Relative density (DR):

$$
\mathrm{DR}=\frac{\text { Species density }}{\text { Total density of all species }} \times 100
$$

Relative abundance (AR):

$$
\mathrm{AR}=\frac{\text { Species abundance }}{\text { Total abundance of all species }} \times 100
$$

$\checkmark \quad$ Relative dominance (DOR):

$\checkmark \quad$ Importance value index (IVI):

$$
\mathrm{DOR}=\frac{\text { Species biomass }}{\sum \text { Total biomass of all species }} \times 100
$$

$$
\mathrm{IVI}=\mathrm{FR}+\mathrm{DR}+\mathrm{AR}
$$

$\checkmark \quad$ Coverage value index (IVC):

$$
\mathrm{IVC}=\mathrm{DOR}+\mathrm{DR}
$$

The floristic similarity index proposed by Sorensen (1972), was determined using the following formula:

$\checkmark \quad$ Similarity index (SI):

$$
\mathrm{SI}=\frac{2 \mathrm{a}}{\mathrm{b}+\mathrm{c}} \times 100
$$

In which $\mathrm{a}$ is the number of species common to both areas, $\mathrm{b}$ and $\mathrm{c}$ are the total number of species in the two compared areas. 


\section{Results and Discussion}

They were found 33 species of weeds belonging to 16 families throughout the evaluation cycle. The families with the largest number of species were Poaceae, Asteraceae, Malvaceae and Euphorbiaceae (Table 1). Maciel et al. (2010) also observed a great predominance of weed species from the Poaceae and Asteraceae families in a phytosociological survey in coffee plantations.

The poaceae family still stands out in crops of several other crops, both annual and perennial, being observed in bean varieties (Silva et al., 2017), cassava (Cardoso et al., 2013; Soares et al., 2015), sugar cane (Soares et al., 2011) papaya (Costa et al., 2019), pineapple (Sarmento et al., 2017), orange (Santos et al., 2015) and mango (Sena et al., 2019). This wide distribution of weeds from the poacea family is directly related to the large amount of seeds produced, which provides an increase in the dissemination power of these species (Maciel et al., 2010).

Table 1. Common names, scientific names and families of weeds identified in the phytosociological surveys carried out in Coffea arabica L. irrigated crops in the North of Minas Gerais

\begin{tabular}{|c|c|c|}
\hline Common name & Scientific name & Family \\
\hline Caruru & Amaranthus spp. & Amaranthaceae \\
\hline Sheep burr & Acanthospermum hispidum & Asteraceae \\
\hline Bulva & Conyza bonariensis & Asteraceae \\
\hline Milkweed & Emilia sonchifolia & Asteraceae \\
\hline White pick & Galinsoga parviflora & Asteraceae \\
\hline Bull Weed & Tridax procumbens & Asteraceae \\
\hline Burr brave & Xanthium strumarium & Asteraceae \\
\hline Trapoeraba & Commelina benghalensis & Commelinaceae \\
\hline Jitirana & Ipomoea hederifolia & Convolvulaceae \\
\hline Viola String & Ipomoea spp. & Convolvulaceae \\
\hline Tiririca & Cyperus rotundus & Cyperaceae \\
\hline Bravo coffee & Croton lobatos & Euphorbiaceae \\
\hline Milkman & Euphorbia heterophylla & Euphorbiaceae \\
\hline Santa Luzia herb & Euphorbia hirta & Euphorbiaceae \\
\hline Forest pasture & Senna obtusifolia. & Fabaceae \\
\hline Bear Ear & Stachys arvensis & Lamiaceae \\
\hline Ground mallow & Pavoni acancellata & Malvaceae \\
\hline White mallow & Sida glaziovii & Malvaceae \\
\hline Malva & Sida spp. & Malvaceae \\
\hline Grass carpet & Mollugo virticillata & Molluginaceae \\
\hline Catch chick & Boerhavia difusa & Nyctaginaceae \\
\hline Brachiaria & Brachiaria decumbens & Poaceae \\
\hline Marmalade grass & Brachiaria plantaginea & Poaceae \\
\hline Carrapicho grass & Cenchrus echinatus & Poaceae \\
\hline Frog hand grass & Dactyloctenium aegyptium & Poaceae \\
\hline Grass mattress & Digitaria horizontalis & Poaceae \\
\hline Bitter grass & Digitaria insularis & Poaceae \\
\hline Chicken foot grass & Eleusine indica & Poaceae \\
\hline Colonião grass & Panicum maximum & Poaceae \\
\hline Grass offered & Pennisetum setosum & Poaceae \\
\hline Beldoegra & Portulaca oleracea & Portualacaceae \\
\hline Poaia & Richardia brasiliensis & Rubiaceae \\
\hline Black mallow & Lantana spp. & Verbenaceae \\
\hline
\end{tabular}

In the sprinkler irrigated area, the greatest diversity of species was registered, with 30 of the 33 species identified in the set of the four surveys (Table 2). This diversity of weed species in the area irrigated by the sprinkler system is directly related to the best growing conditions of the plants between the coffee lines, provided by the greater water availability due to the system's water distribution pattern, as the constant water supply in the lines and between the lines of planting tends to favor the development of weeds (Andres et al., 2012). 
Among the species found in the area irrigated by sprinkling, the highlights were the Euphorbia hirta, Cyperus rotundus and Digitaria horizontalis which presented a greater number of individuals per species in two of the four seasons (Table 2), indicating that these species are present in the area for most of the year. In addition to presenting the largest number of individuals per species, the species C. rotundus and D. horizontaliss tood out for presenting a higher dry mass value in the summer and autumn seasons (Table 2), characterizing them as species that have greater capacity for extracting soil resources.

Table 2. Number of individuals per species (NIE) and dry mass (MS) of weeds identified in blond Coffea arabica L. irrigated by sprinkling in the spring (Sprin.), summer (Sum.), autumn (Aut.) and winter (Win.) seasons, in the North of Minas Gerais

\begin{tabular}{|c|c|c|c|c|c|c|c|c|}
\hline \multirow{2}{*}{ Weed } & \multicolumn{4}{|c|}{ NIE } & \multicolumn{4}{|c|}{ MS (g) } \\
\hline & Sprin. & Sum. & Aut. & Win. & Sprin. & Sum. & Aut. & Win. \\
\hline Euphorbia hirta & 266 & 251 & 46 & - & 11.7 & 98.8 & 28.3 & - \\
\hline Brachiaria plantaginea & 152 & - & - & - & 29.6 & - & - & - \\
\hline Conyza bonariensis & 129 & 3 & - & 22 & 163.5 & 2.7 & - & 20.8 \\
\hline Portulaca oleracea & 102 & 14 & 5 & - & 15.9 & 4.4 & 6.4 & - \\
\hline Amaranthus spp. & 47 & 5 & 2 & 34 & 4.0 & 16.4 & 16.4 & 46.9 \\
\hline Commelina benghalensis & 41 & 35 & 15 & 31 & 21.6 & 42.2 & 56.3 & 57.6 \\
\hline Cyperus rotundus & 25 & 123 & 325 & 100 & 1.5 & 112.1 & 682.9 & 73.4 \\
\hline Boerhavia difusa & 13 & - & 2 & 37 & 1.5 & - & 13.0 & 9.2 \\
\hline Mollugo virticillata & 9 & 22 & 331 & 15 & 0.4 & 2.6 & 189.4 & 7.4 \\
\hline Galinsoga parviflora & 6 & 1 & - & - & 0.5 & 0.2 & - & - \\
\hline Sida spp. & 4 & 3 & 4 & - & 1.3 & 1.8 & 1.1 & - \\
\hline Xanthium strumarium & 3 & - & - & - & 0.1 & - & - & - \\
\hline Euphorbia heterophylla & 2 & 3 & 3 & - & 0.7 & 9.8 & 1.9 & - \\
\hline Tridax procumbens & 2 & 20 & - & - & 0.8 & 24.7 & - & - \\
\hline Panicum maximum & - & 1 & - & 27 & - & 0.8 & - & 142.9 \\
\hline Richardia brasiliensis & - & - & 51 & 117 & - & - & 71.2 & 111.5 \\
\hline Eleusine indica & - & 5 & 24 & 10 & - & 17.6 & 106.2 & 98.6 \\
\hline Emilia sonchifolia & - & 27 & 4 & 50 & - & 19.6 & 0.8 & 41.3 \\
\hline Sida glaziovii & - & - & 4 & 42 & - & - & 2.7 & 39.2 \\
\hline Digitaria horizontalis & - & 225 & 199 & 20 & - & 223.1 & 283.6 & 25.5 \\
\hline Stachys arvensis & - & - & - & 7 & - & - & - & 16.6 \\
\hline Acanthospermum hispidum & - & - & - & 2 & - & - & - & 10.0 \\
\hline Digitaria insularis & - & 2 & 17 & - & - & 4.2 & 62.2 & - \\
\hline Cenchrus echinatus & - & 27 & 9 & - & - & 18.9 & 40.8 & - \\
\hline Pavonia cancellata & - & - & 18 & - & - & - & 33.6 & - \\
\hline Ipomoea spp. & - & 2 & 13 & - & - & 3.2 & 27.1 & - \\
\hline Ipomoea hederifolia & - & 15 & 1 & - & - & 28.2 & 5.0 & - \\
\hline Senna obtusifolias & - & 21 & - & - & - & 13.2 & - & - \\
\hline Brachiaria decumbens & - & 4 & - & - & - & 8.0 & - & - \\
\hline Dactyloctenium aegyptium & - & 7 & - & - & - & 4.2 & - & - \\
\hline Total & 801 & 816 & 1,073 & 514 & 253.2 & 656.6 & $1,628.9$ & 700.9 \\
\hline
\end{tabular}

The species of the genus Cyperus have a great competitive capacity, which can be found affecting different cultures, these weeds have wide adaptation, being found in all types of soil and climate, in addition, it has good dissemination with both sexual and asexual reproduction (Monquero, 2014). The importance of C. rotundus is even more evident as it is a kind of difficult chemical and/or mechanical control (Moreira et al., 2013)

In the drip irrigated area, 27 of the 33 species identified were found throughout and all surveys, of these, highlighted the Amaranthus spp. and the E. hirta that were present in the field throughout the year with a greater number of individuals per species in all seasons. These same species still showed high dry matter values in the seasons and spring, autumn and winter (Table 3). 
Table 3. Number of individuals per species (NIE) and dry mass (MS) of weeds identified in blond Coffea arabica L. drip irrigated in the spring (Sprin.), summer (Sum.), autumn (Aut.) and winter (Win.) seasons, in the North of Minas Gerais

\begin{tabular}{|c|c|c|c|c|c|c|c|c|}
\hline \multirow{2}{*}{ Weed } & \multicolumn{4}{|c|}{ NIE } & \multicolumn{4}{|c|}{ MS (g) } \\
\hline & Sprin. & Sum. & Aut. & Win. & Sprin. & Sum. & Aut. & Win. \\
\hline Amaranthus spp. & 45 & 313 & 17 & 27 & 83.0 & 4.6 & 91.3 & 69.0 \\
\hline Euphorbia hirta & 24 & 161 & 123 & 93 & 19.1 & 3.2 & 94.9 & 45.5 \\
\hline Tridax procumbens & 24 & - & 11 & 10 & 17.1 & - & 24.4 & 39.9 \\
\hline Sida spp. & 13 & 12 & 2 & 1 & 25.1 & 1.5 & 10.3 & 10.3 \\
\hline Portulaca oleracea & 3 & 805 & 9 & 10 & 1.6 & 14.4 & 1.0 & 21.9 \\
\hline Commelina benghalensis & 3 & - & 14 & 5 & 3.9 & - & 67.2 & 11.8 \\
\hline Brachiaria plantaginea & 2 & - & - & 2 & 6.1 & - & - & 18.5 \\
\hline Conyza bonariensis & 2 & - & - & - & 3.8 & - & - & - \\
\hline Brachiaria decumbens & 1 & - & - & - & 0.8 & - & - & - \\
\hline Ipomoea spp. & 1 & - & - & - & 0.3 & - & - & - \\
\hline Digitaria horizontalis & - & 13 & 54 & 68 & - & 0.5 & 129.3 & 71.9 \\
\hline Cenchrus echinatus & - & - & 5 & 6 & - & - & 11.9 & 49.3 \\
\hline Panicum maximum & - & - & - & 5 & - & - & - & 37.8 \\
\hline Sida glaziovii & - & - & 1 & 3 & - & - & 1.6 & 35.2 \\
\hline Richardia brasiliensis & - & - & 3 & 13 & - & - & 23.3 & 31.0 \\
\hline Boerhavia difusa & - & - & 4 & 5 & - & - & 70.0 & 11.9 \\
\hline Cyperus rotundus & - & - & 9 & 4 & - & - & 5.9 & 6.5 \\
\hline Pennisetum setosum & - & - & - & 3 & - & - & - & 6.4 \\
\hline Dactyloctenium aegyptium & - & - & 1 & 1 & - & - & 3.3 & 3.9 \\
\hline Euphorbia heterophylla & - & - & - & 1 & - & - & - & 2.7 \\
\hline Croton lobatos & - & - & - & 1 & - & - & - & 2.1 \\
\hline Eleusine indica & - & - & 17 & - & - & - & 59.4 & - \\
\hline Pavonia cancellata & - & - & 5 & - & - & - & 28.2 & - \\
\hline Mollugo virticillata & - & - & 2 & - & - & - & 10.0 & - \\
\hline Lantana spp. & - & - & 6 & - & - & - & 4.3 & - \\
\hline Galinsoga parviflora & - & 7 & - & - & - & 16.2 & - & - \\
\hline Ipomoea hederifolia & - & 32 & - & - & - & 9.5 & - & - \\
\hline Total & 118 & 1,343 & 286 & 258 & 160.8 & 49.8 & 643.4 & 475.6 \\
\hline
\end{tabular}

The conditions of a drip irrigated production system can favor the greater development of weeds in the dicocotyledonous group, this due to the lower water availability, whereas in the sprinkler irrigated system, monocotyledonous weed infestation tends to be greater between the lines due to continuous and uniform water supply in the area.

Mendes et al. (1995), working with coffee, they also state that in the dry period, with less surface water availability, there is a greater predominance of dicotyledonous weeds because they have a deeper root system, as in the case of Amaranthus spp., while in the rainy season there is a greater predominance of monocotyledonous weeds, whose root system, which is more superficial, is stimulated by the greater availability of water. Thus, these authors corroborate with the information that weed infestation in the group of dicots and monocots is closely related to the availability of water resources in the soil.

In all the surveys carried out, both in coffee plants irrigated by sprinkling and dripping, the presence of $E$. hirta among the species with the highest IVI (Figure 2) phytosociological parameters, relative density and relative abundance, which contributed most to this index. 

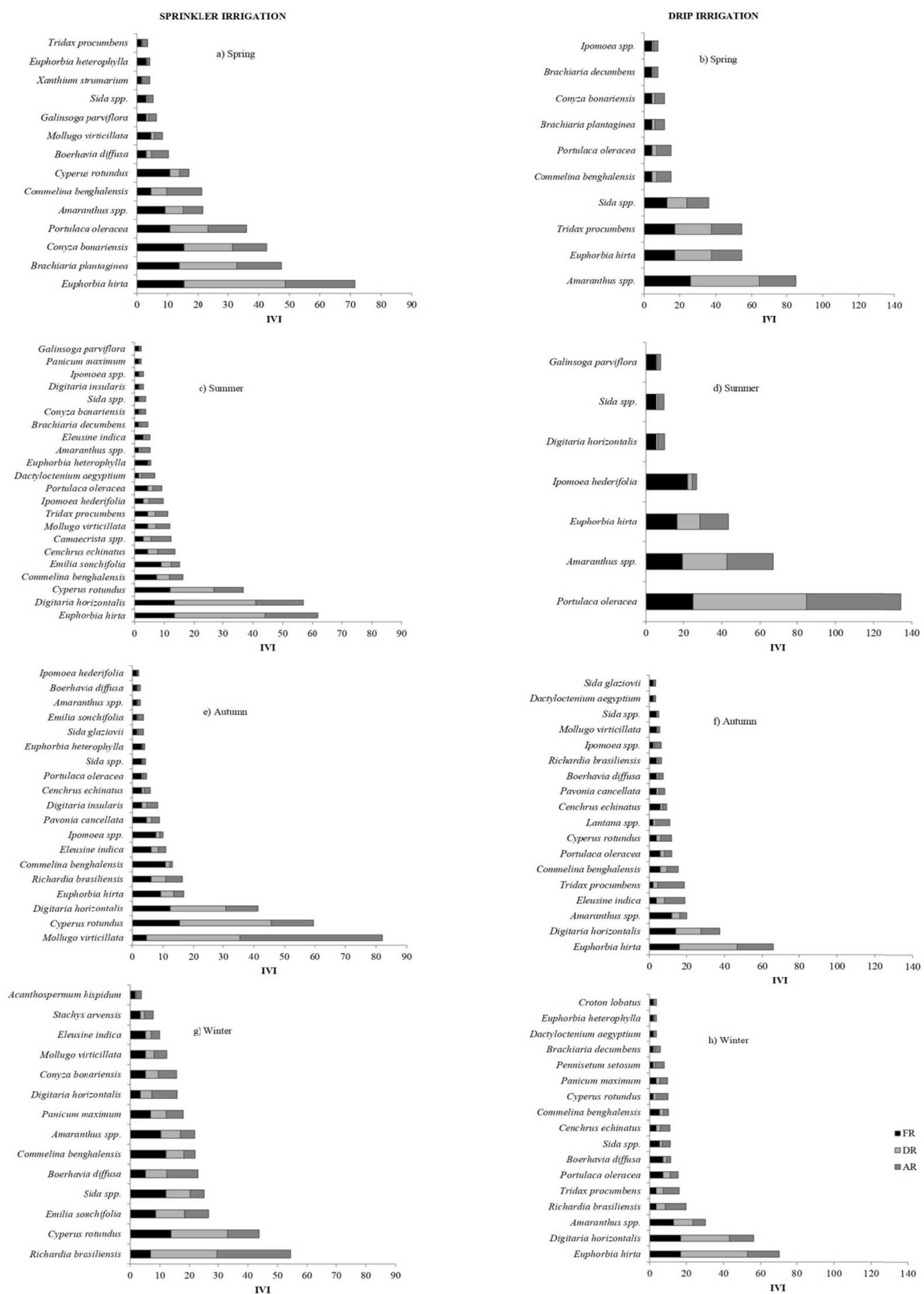

Figure 2. Relative Frequency (FR), relative density (DR), relative Abundance (AR) and importance value index (IVI) of weed species in weeds Coffea arabica L. irrigated by sprinkling and dripping in the

North of Minas Gerais 
The E. hirta it is a herbaceous plant, prostrate in size, measuring $10-50 \mathrm{~cm}$ in length. It is a weed with wide distribution and is found in annual crops, seedling nurseries and perennial crops. Its propagation occurs through seeds having a plant with a production capacity of up to 3,000 seeds. The establishment of this species occurs in general in dry soils with high sun exposure since it has the need for light for its germination, which justifies the high value of IVI of this species, especially in the drip irrigated area. In addition to the competition of this species with other plants, for water, light and nutrients, the E. hirta it is also an alternative host of nematodes, characteristics that can directly influence the potential of the crop (CABI, 2019).

The occurrence of species Brachiaria plantaginea and D. horizontalis it was also common to areas irrigated by both sprinkling and dripping throughout the year, with a high importance value index (Figure 2). These same species have also been identified by Silva et al. (2013) assessing the occurrence of weeds in the arabica coffee culture intercropped with walnut-macadamia, with great relative importance in both single and intercropping.

Relative importance is a parameter that indicates which species are most important in terms of infestation, taking into account their distribution, the number of individuals and the concentration in the area. Kuva et al. (2007) explain that in a weed-infested community, not all species present will have the same degree of importance as interference in crop development and productivity. Within the infesting community there will be dominant species, responsible for most of the interference, the secondary species, present in a lower density and coverage, and the companions, which occur occasionally and hardly cause economic problems to the crops. Thus, before determining a control strategy, it is necessary to establish an order of priorities among the species present in the area for the control to take place efficiently.

In the drip irrigated area, the species Amaranthus spp. was present in the phytosociological survey during the 4 seasons of the year among the species with the highest IVI (Figure 2). This fact is mainly due to the morphophysiological characteristics of this plant. The $\mathrm{C} 4$ metabolism, as well as the aggressive growth habit and the prolific seed production, offer Amaranthus plants a high competitive capacity for light, water and nutrients, managing to establish themselves in more adverse edaphoclimatic conditions. According to Klink and Joly (1989), generally, species that have a C4 type carbon assimilation cycle are more adapted to environments with high light radiation as well as conditions of limited water availability, which implies high competition with the crop of interest.

The species Conyza bonariensis and Richardia brasiliensis stood out only in the spring and winter seasons, respectively among the species with the highest IVI in the sprinkler irrigated area. Similarly, the species Portulaca oleracea and Tridax procumbens presented high IVI only in the spring and summer seasons, respectively, in the drip irrigated area. This diversification in the establishment of weeds throughout the year can be influenced by weather conditions, cultural practices and seed bank (Adegas et al., 2010). In addition, they still have different cycles and behavior, which justifies their appearance in specific periods.

In general, the species that presented the highest importance value index (IVI) also presented a higher coverage value index (IVC), highlighting the Amaranthus spp. for all seasons of the year in the drip irrigated area and the E.hirta and $D$. horizontalis which was common for both irrigation systems being among the species with the highest IVC value (Figure 3). However, in the sprinkler irrigated area in the winter season it was found that the species Panicum maximum and Eleusine indica stood out among the species with the highest IVC although they had lower IVI values. This result is explained by the high dry matter value obtained by these species, which is not considered in the determination of the IVI while the IVC takes into account the species' biomass production as a function of the number of individuals per area. This parameter highlights the ability of weeds to compete due to their ability to cover the soil and their interference in the incidence of other species.

The data obtained in the present study allow us to infer that the weed flora in the coffee crop changes over the seasons, as well as between different irrigation systems (Figures 2 and 3). Thus, the recognition of weed species becomes essential to understand the dynamics of the weed flora and to determine prevention and management programs and strategies to be adopted efficiently (Adegas et al., 2010; Dangwal et al., 2011; Salomão et al., 2012). 

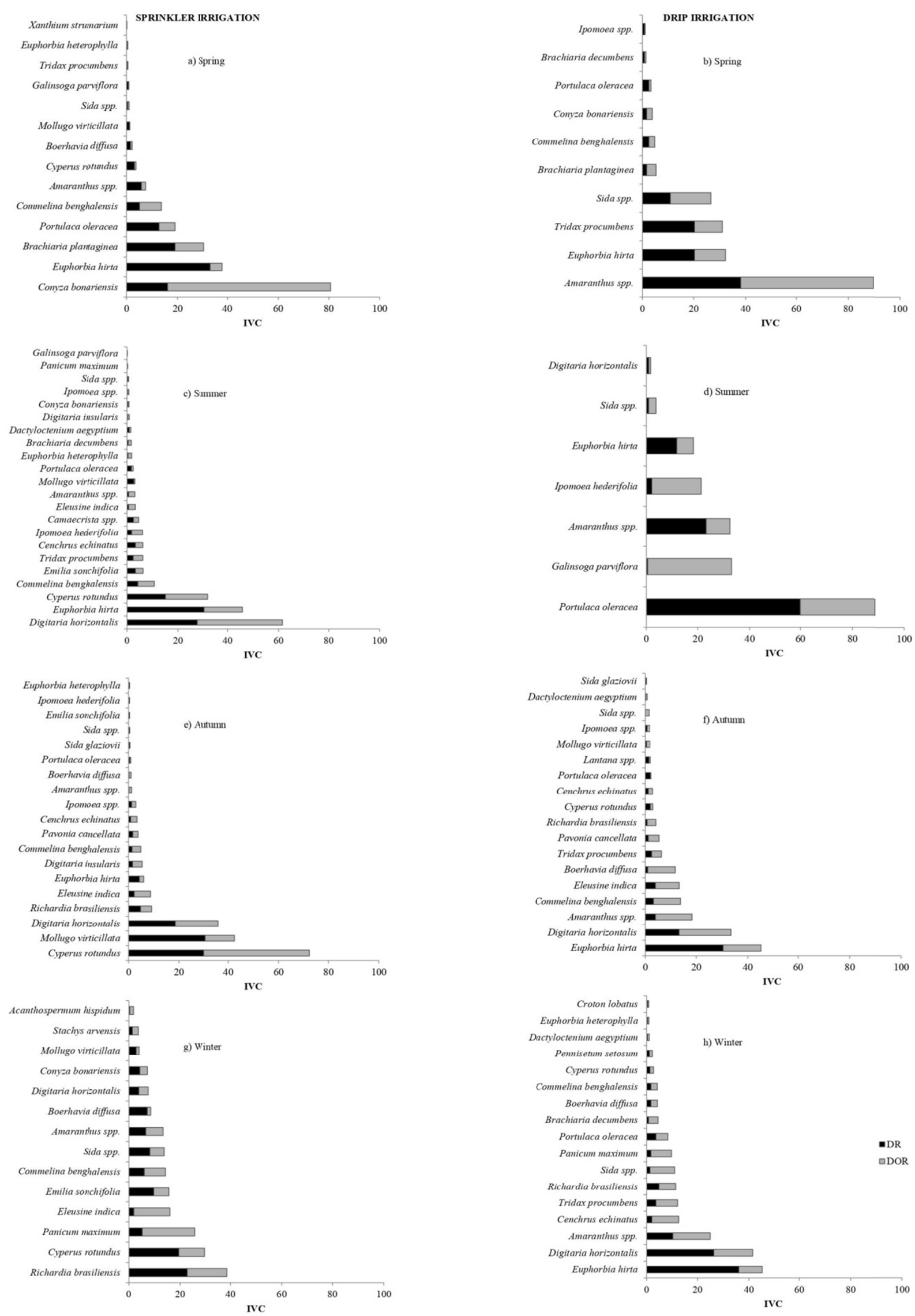

Figure 3. Relative density (DR), relative dominance (DOR) and coverage value index (IVC) of weed species in weeds Coffea arabica L. irrigated by sprinkling and dripping in the North of Minas Gerais 
As for the weed similarity index between the areas irrigated by sprinkling and dripping throughout the year, it found a high value suggesting that $81.36 \%$ of the species identified in the survey are common to the two irrigation systems evaluated (Table 4).

Table 4. Similarity index of weed communities occurring in Coffea arabica L. sprinkled and drip irrigated in northern Minas Gerais at different seasons

\begin{tabular}{ll}
\hline Comparison Criteria & Similarity index $(\%)$ \\
\hline Sprinkling $\times$ Dripping & 81.36 \\
\hline
\end{tabular}

According to Felfili and Venturoli (2000), similarity index values greater than $50 \%$ are considered high. However, it is noteworthy that the calculation fins were considered throughout the evaluation period, disregarding the effect of the seasons, or that justifies a high similarity between areas. Kuva et al. (2007) still explain that the floristic similarity index is a parameter that considers only the absence or presence of the species or set of plants, and is usually calculated according to the individual species present in the areas, neglecting density, biomass and distribution pattern information.

\section{Conclusion}

In the conditions of the North of Minas Gerais, the weed flora in weeds in irrigated coffee is mostly constituted by species belonging to the families Poaceae, Asteraceae and Euphorbiaceae, with greater diversity of weed species in a sprinkler irrigation system when compared to the drip system. In sprinkler-irrigated coffee plants there is a greater predominance of monocotyledonous weeds, while in drip-irrigated areas the infesting flora is predominantly composed of dicotyledonous species.

\section{References}

Adegas, F. S., Oliveira, M. F., Vieira, O. V., Prete, C. E. C., Gazziero, D. L. P., \& Voll, E. (2010). Phytosociological survey of weeds in sunflower crop. Planta Daninha, 28(4), 705-716. https://doi.org/ $10.1590 / \mathrm{S} 0100-83582010000400002$

Andres, A., Concenco, G., Theisen, G., Galon, L., \& Tesio, F. (2012). Management of red rice (Oryza sativa) and barnyardgrass (Echinochloa crus-galli) grown with sorghum with reduced rate of atrazine and mechanical methods. Experimental Agriculture, 48(4), 587-596. https://doi.org/10.1017/S0014479712000671

Braun-Blanquet, V. (1979). Fitosociología, bases para el estudio de las comunidades vegetales (p. 820). Madrid: H. Blume.

CABI (Cookies on Invasive Species Compendium). (2019). Euphorbia hirta. Retrieved December 6, 2019, from http://www.cabi.org/isc/datasheet/21355

Cardoso, A. D., Viana, A. E. S., Barbosa, R. P., Teixeira, P. R. G., Cardoso Júnior, N. D. S. C., \& Fogaça, J. J. N. L. (2013). Levantamento fitossociológico de plantas daninhas na cultura da mandioca em Vitória da Conquista, Bahia. Bioscience Journal, 29(5), 1130-1140.

CONAB (Compampahia Nacional de Abastecimento). (2019). Acompanhamento da safra brasileira: Café (Vol. 5, Safra 2019, No. 2, Segundo Levantamento, p. 61). Brasília, Brazil.

Costa, R. N., Silva, D. M. R., Rocha, A. O., Lima, A. N. S., Santos, J. C. C., Silva, L. K. S., \& Acchile, S. (2019). Levantamento fitossociológico de plantas daninhas em área de produção de mamão. Revista Científica Rural, 21(3), 183-193. https://doi.org/10.30945/rcr-v21i3.2790

Dangwal, L. R., Singh, A., Singh, T., \& Sharma, A. (2011). Common weeds of kharif crops of Block Sunderbani District Rajouri (Jammu and Kashmir). Pakistan Journal of Weed Science Research, 17, 9-15.

Felfili, J. M., \& Venturoli, F. (2000). Tópicos em análise de vegetação. Comunicações Técnicas Florestais, 2(2), $1-25$.

Gomes, G. L. G. C., Ibrahim, F. N., Macedo, G. L., Nobrega, L. P., \& Alves, E. (2010). Cadastramento fitossociológico de plantas daninhas na bananicultura. Planta Daninha, 28(1), 61-68. https://doi.org/ $10.1590 / \mathrm{S} 0100-83582010000100008$

Guimarães, P. T. G., Garcia, A. W. R., Alvarez, V. H., Prezotti, L. C., Viana, A. S., \& Miguel, A. E. (1999). Cafeeiro. In A. C. Ribeiro, P. T. G. Guimarães, \& V. H. Alvarez-Venegas (Eds.), Recomendações para o uso de corretivos e fertilizantes em Minas Gerais-5a aproximação (pp. 289-302). Viçosa, MG: CFSEMG. 
Klink, C. A., \& Joly, C. A. (1989). Identification and distribuition of C3 and C4 grasses in open and shaded habitats in São Paulo State, Brazil. Biotropica, 21, 30-34. https://doi.org/10.2307/2388438

Kuva, M. A., Pitelli, R. A., Salgado, T. P., \& Alves, P. L. C. A. (2007). Fitossociologia de comunidades de plantas daninhas em agroecossistema cana crua. Planta Daninha, 25(3), 501-511. https://doi.org/10.1590/S010083582007000300009

Maciel, C. D. G., Poletine, J. P., Oliveira, N., Guerra, N., \& Justiniano, W. (2010). Weeds phytosociological survey in organic coffee crop. Bragantia, 69(3), 631-636. https://doi.org/10.1590/S0006-87052010 000300015

Mendes, A. N. G., Abrahão, E. J., Cambraia, J. F., \& Guimarães, R. J. (1995). Recomendações técnicas para a cultura do cafeeiro no sul de Minas (p. 76). Lavras: UFLA.

Monquero, P. A. (2014). Aspectos da biologia e manejo das plantas daninhas. São Carlos: RiMa Editora.

Moreira, G. M., Oliveira, R. M., Barrella, T. P., Fontanétti, A., Santos, R. H. S., \& Ferreira, F. A. (2013). Fitossociologia de plantas daninhas do cafezal consorciado com leguminosas. Planta Daninha, 31(2), 329-340. https://doi.org/10.1590/S0100-83582013000200010

Pitelli, R. A. (1985). Interferência das plantas daninhas em culturas agrícolas. Informe Agropecuário, 11(129), 16-27.

Salomão, R. P., Santana, A. C., \& Costa Neto, S. V. (2012). Construção de índices de valor de importância de espécies para análise fitossociológica de floresta ombrófila através de análise multivariada. Floresta, 42(1), 115-128. https://doi.org/10.5380/rf.v42i1.26307

Santos, C. S., Santos, J. C. C., Melo, E. B., Matos, R. M., \& Silva, P. F. (2015). Levantamento fitossociológico de plantas daninhas na cultura da laranja. Journal of Agronomic Sciences, 4(2), 50-59.

Sarmento, H. G. S., Rodrigues, T. M., Aspiazú, I., \& Corsato, C. E. (2017). Phytosociological survey in pineapple cultivated in northern Minas Gerais. Nativa, 5(4), 231-236. https://doi.org/10.5935/2318-7670. v05n04a01

Sena, F. H. S., Aspiazú, I., Silva, N. P., Oliveira, R. M., Silva, K. M. J., Matrangolo, C. A. R., \& Brito, C. F. B. (2019). Levantamento fitossociológico de plantas daninhas em pomares de mangueira no semiárido mineiro. Nativa, 7(5), 500-505. https://doi.org/10.31413/nativa.v7i5.7170

Silva, D. M. R., Santos, J. C. C., Silva, C. H., Santos, A. S., \& Costa, R. N. (2017). Levantamento fitossociológico: Interferência de plantas espontâneas associadas ao cultivo de feijão carioca. Revista Agrotecnologia, 8(2), 37-43. https://doi.org/10.12971/2179-5959/agrotecnologia.v8n2p37-43

Silva, V. D. C., Perdoná, M. J., Soratto, R. P., \& Negrisoli, E. (2013). Ocorrência de plantas daninhas em cultivo consorciado de café e nogueira-macadâmia. Pesquisa Agropecuária Tropical, 43(4), 441-449. https://doi.org/10.1590/S1983-40632013000400013

Soares, M. B. B., Finoto, E. L., Bolonhezi, D., Carrega, W., Albuquerque, J. A. A., \& Pirotta, M. Z. (2011). Fitossociologia de plantas daninhas sob diferentes sistemas de manejo de solo em áreas de reforma de cana crua. Revista Agro@mbiente Online, 5(3),73-181. https://doi.org/10.18227/1982-8470ragro.v5i3.594

Soares, M. R. S., São José, A. R., Araujo Neto, A. C., Lima, R. S., Moreira, E. S., \& Prado, T. R. (2015). Phytosociological survey of weed in cassava cultivation in Southwestern Bahia, Brazil. African Journal Agricultural Research, 10(20), 2120-2129. https://doi.org/10.5897/AJAR2015.9581

Sorensen, T. A. (1972). Method of stablishing groups equal amplitude in plant society based on similarity of species content. In E. P. Odum (Ed.), Ecologia (3rd ed., pp. 341-405). México: Interamericana.

\section{Copyrights}

Copyright for this article is retained by the author(s), with first publication rights granted to the journal.

This is an open-access article distributed under the terms and conditions of the Creative Commons Attribution license (http://creativecommons.org/licenses/by/4.0/). 